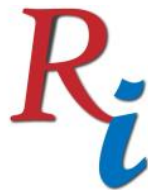

Asia Proceedings of Social Sciences

(APSS)

www.readersinsight.net/APSS

\title{
INTEGRATING PROJECT BASED LARNING INTO WOODWORK TECHNOLOGY EDUCATION IN NIGERIAN TERTIARY INSTITUTIONS
}

\section{Muhammad Umar Isa*}

Department of Ttechnical and Engineering Education University Teknology Malaysia

Malaysia

\section{Yusri Bin Kamin}

Department of Ttechnical and Engineering Education University Teknology Malaysia

Malaysia

*Corrosponding author's Email: uisa483@gmail.com

Author's Biography

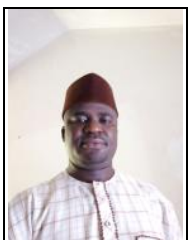

Peer-review under responsibility of $3^{\text {rd }}$ Asia International Multidisciplanry Conference 2019 editorial board (http://www.utm.my/asia/our-team/) (C) 2019 Published by Readers Insight Publisher, lat 306 Savoy Residencia, Block 3 F11/1,44000 Islamabad. Pakistan, 


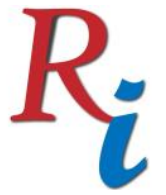

Asia Proceedings of Social Sciences

(APSS)

www.readersinsight.net/APSS

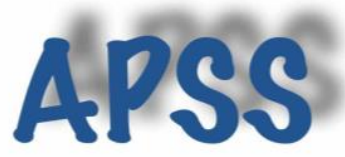

\section{Rese a r ch H i g h I igh t s}

The focus of this study is on integrating project based learning in woodwork technolgy education at Nigerian tertiary instirutions. Three reseach questions were posed in the study. A sequential explanatory design was employed for the study. The results from the study revealed that project based learning is not implemented in Nigeria tertiary institutions. It was revealed from the results of the study that traditional method of instruction is the main instructional approach adopted in Nigerian tertiary institutions. The study Findings also revealed that curriculum of WTE needs to be restructured to focus on $21^{\text {st }}$ century skills through the integration of project based learning for effectiveness in students skill acquisition in WTE.

\section{Research Objectives}

The main objective of this study is to investigate effective strategies for integrating projectbased learning in woodwork technology education at Nigerian tertiary institutions.

This study will be of significance to woodwork students, lecturers and curriculum planners. For the lecturers using PoBL in WTE will assist in improving lecturers instructional approaches through shifting from teacher centered approach to student centered learning approach which will enhance student's participation and performance in WTE. Students of WTE at tertiary institutions will benefit from this study as the findings will assist the student them in exploring their potentials in woodwork technology through engagement in collaboration with each other, critical thinking on how to solve a real-life problem and improvement in student's communication skills. Woodwork technology education Curriculum planners at various levels of tertiary institutions will use the findings from this study as a guide in restructuring the curriculum of woodwork technology education at tertiary institution towards $21^{\text {st }}$ century learning.

\section{Methodology}

A sequential explanatory design was adopted for this study. A sequential explanatory design involves the collection and analysis of quantitative data in a first phase of a study followed by the collection and analysis of qualitative data in a second phase that explains the results of the initial quantitative data (Creswell, 2014). To begin, a survey questionnaire was used to investigate the research questions, and later a semi structured interview was conducted to examine the results from the quantitative on the instructional strategies adopted in WTE teaching and learning and the strategies for integrating PoBL in WTE at tertiary institutions of Nigeria. The population in this study comprised 50 in service post graduate students from Nigerian tertiary institutions pursuing postgraduate studies in Technical and Vocational Education and Training (TVET) at Universiti Teknologi Malaysia purposively sampled as respondents for this study.

The instrument used for collecting data is in two forms.Questionnaire involving five point Likert scale was used for collecting qualitative data, while semi structured interview was used for collecting qualitative data. SPSS version 24 was used to process data obtained from the questionnaire.

\section{Results}

Results from the quantitative data revealed that $80 \%$ of the respondents agreed that lecture, demonstration, discussion methods are the predominant method of instruction used in tertiary institutions of Nigeria, indicating that the conventional method of instruction is the main 


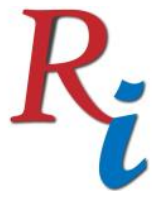

\section{Asia Proceedings of Social Sciences (APSS) \\ www.readersinsight.net/APSS}

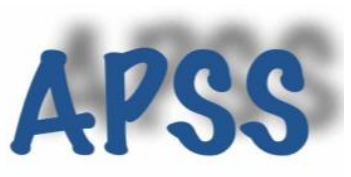

instruction adopted in WTE at tertiary institutions of Nigeria. The results of the quantitative data also shows that $90 \%$ of the respondents agreed that motivation, improvement of student $21^{\text {st }}$ century skills as well as fostering student ownership of learning were among the benefits for integrating PoBL in WTE. The result also revealed that $78 \%$ of the respondents agreed that curriculum restructure, adequate training of lecturers on adoption of PoBL implementation in WTE were the strategies for iintegrating PoBL in WTE.

Qualitative results generated from the interview themes revealed that $74 \%$ of the respondents stated that lecture, discussion and demonstration are the instructional aprooaches adopted in WTE, and also opined that PoBL is not adopted in WTE. Based on the qualitative results, it was opined by $65 \%$ of the respondents that organising workshops and semionar for WTE lecturers, enforcing adoption of PoBL in WTE and Restructuring of WTE curriculum as the strategies of integrating PoBL in WTE.

\section{Findings}

Findings from both quantitative and qualitative result revealed that traditional method of instructiona involving lecture, demonstration and discussion are the predominant method of instruction in tertiary instirutions of Nigeria and that projexct based learning is raely adopted. This is in line with Umar (2014) and Peter, Abiodun \& Johnathan (2010)who stated that WTE is faced with cahllenges of adopting obsollete instructional methods in imparting knowledge ans skills to students. The findings als revealed that in order to integrate PoBL in WTE, the curriculum needs to be restructured and adequate training be given to lectures on Pobl implementation . This is in line with Chinonso( 2017), Umar \& Maaji(20110) who stated that the curriculum of woodwork needs to be restructure to a $21^{\text {st }}$ century learning.

\section{References}

Chinonso, O.O. (2017). Management of woodwork workshops in Nigerian tertiary institutions: An analytical study. Malay. Online J. Educ. Manage, 2(1),20-36.

Creswell, J. W. (2014). A concise introduction to mixed methods research. Sage Publications.

Peter, O. I., Abiodun, A. P., \& Jonathan, O. O. (2010). Effect of constructivism instructional approach on teaching practical skills to mechanical related trade students in western Nigeria technical colleges. International NGO Journal, 5(3), 059-064.

Umar, L. (2014). Skills Required by Teachers to Carry out Their Activities in Wood workshops in Tertiary Institutions in North Wester Nigeria. Journal of Education and Social Sciences Research, 4 (7), 108-114.

Umar, I. Y., \& Ma'aji, A. S. (2010). Repositioning the Facilities in Technical College Workshops for Efficiency: A Case Study of North Central Nigeria. Journal of STEM Teacher Education, 47 (3), 63-85. 